\title{
THE SIGNIFICANCE OF ENTREPRENEURIAL LEADERSHIP TOWARDS MALAYSIAN SCHOOL PERFORMANCE: MEDIATOR BY EMPOWERMENT
}

\author{
Norhisham Mohd Kasim ${ }^{1}$ \\ Faculty of Entrepreneurship \& Business, Universiti Malaysia Kelantan \\ (Email: norhishambinmohdkasim@gmail.com) \\ Mohd Nazri Zakaria ${ }^{2}$ \\ Faculty of Entrepreneurship \& Business, Universiti Malaysia Kelantan \\ (Email: mnazri.z@umk.edu.my)
}

Accepted date: $13-06-2019$

Published date: 09-07-2019

To cite this document: Kasim, N. M., \& Zakaria, M. N. (2019). The Significance of Entrepreneurial Leadership towards Malaysian School Performance: Mediator by Empowerment. International Journal of Education, Psychology and Counseling, 4(31), 409426.

DOI: $10.35631 /$ IJEPC.4310035

\begin{abstract}
School performance is a main agenda in school organization to achieving the vision and mission as well as the main objectives of the Ministry of Education. Issues on performance in the context of school organization are based on leadership management. The main issues highlighted are based on leadership in achieving the ultimate goal of the Ministry of Education (MOE). This study examines the leadership among the headmasters and principals in schools in improving the performance of schools in Malaysia. From the concept of leadership, the leadership that forms the leadership of entrepreneurship among teachers in every school leader plays an important role in the education system to deal with changes and challenges. Entrepreneurial leadership is a leader who is classified to achieve the same goal of using entrepreneurial behavior. Hence, this study focuses for entirely on entrepreneurial leadership relationship with school performance in Malaysia. Supported by the Model Leader Member Exchange theory, this study proposes a framework by outlining the factors that exist in entrepreneurial leadership and empowering. A total of 171 school administrators from public schools were participated in this study. Data for this study variables were collected through a self-administered survey. Structural Equation Modeling (SEM) is the main statistical technique used in this study. The findings show that some variables such as entrepreneurial leadership and empowerment are significant in relation to school performance. The findings will contribute to future research that researchers can research deeply on the performance of public or private schools in Malaysia.
\end{abstract}

Keywords: Entrepreneurial Leadership, School Performance And Empowerment 


\section{Introduction}

Academicians have identified several issues regarding to the organization performance. They have identified performance from global perspective issues which highlighted by three main factors leadership, process and result (Hocevar, Janzen \& Wilson, 2012). However, Lu, Zhu and Bao (2015) mentioned that performances are distinguished by excellent leadership and dynamic leaders who are committed to the success of organizational variables. The effective leader is a leader who played a role as a visionary leader who is clear about his organization, employees and result. Performance in school organization also distinguished by excellent leadership and dynamic leaders in controlling their process and students achievement towards effectiveness school (Rahimah \& Ghavifekr, 2014). The issues of leadership towards performance are similarity to the factors contribute to the school performance. There are a lot of factors that significance to the school performance excluding leadership. Shaked and Schechter (2014), mentioned that leadership element needs to investigate because of not influencing indirectly and evaluating significance toward school performance. In general requirement of the demands to improve the performance of the school is very urgent especially with the availability of internationally competitive today (Jones \& Harris, 2014).

The issue of preparing and developing school leaders has a long history of research and empirical inquiry in the performance perspective. Malaklolunthu and Shamsudin (2011) emphasize the importance of developing school and need to investigate for school leaders in their distinctive role as educational leaders. This same priority is reflected in Malaysia, as a new mandatory qualification, the National Professional Qualification for Educational Leaders (NPQEL), for all new school leaders has recently been introduced (Institut Aminudin Baki, 2014). Leithwood and Sun (2012) reinforce that leadership strategies are crucial, within an educational setting, to secure better performance and outcomes. As emphasized earlier, school leaders in Malaysia are now viewed as transformational leaders who are expected to lead change and improve performance in line with national expectations (Malaklolunthu \& Shamsudin, 2011). This means that, Malaysia school leaders are now expected to bring about change in their schools and to improve school performance year on year (Tie, 2012). Malaysia are now expected to create the different leadership in developing the goals, mission and values of the school toward to the global challenges as the transformational (Rahimah \& Ghavifekr, 2014). Therefore, Pihie et al., (2014) introduce a different leadership in school organization as an entrepreneurial leadership in facing all the barriers, environment and global challenges in order to improve the school performance.

There are several studies regarding to the elements of entrepreneurial leadership regarding to the performance and achievement of the organization. Park (2012) found a significant relationship between school leaders and support for innovation at schools. Eyal and Inbar (2013) found that the relationship between primary school principals' proactiveness and school innovativeness. They defined school principals' proactiveness as the willingness to start intrinsically motivated actions and found that proactive leadership has a good impact in improving a school organization. Keempster and Cope (2010) mentioned that risk taking is the best of the willingness of entrepreneurial leadership to absorb uncertain environment and take on big responsibility and challenge for the future. In addition, entrepreneurial leadership is considered as having a superior tendency to take risks than cope and need to take a different risk in a various platform of their project and organization growth. Renko, Tarabishy, Carsrud and Brannback (2015) mentioned that creativity in entrepreneurial leadership was influencing and directing the performance of group members towards the achievements of those organizational goals which involve recognizing and exploiting entrepreneurial opportunities. 
Fontana et al., (2017) mentioned that innovation of entrepreneurial leadership has a significance relationship to the performance, Ruvio et al., (2010) mentioned that entrepreneurial leadership has significance relationship to the nonprofit organization. Renko et al., (2015) also mentioned that creativity of entrepreneurial leadership has a significance relationship to the organization. Based on the argument of the relationship between the elements of entrepreneurial leadership, conclude that dimension of entrepreneurial leadership has significance relationship toward organization achievement either in profit or nonprofit organization.

Therefore, this study needs a mediator as a mechanism through which the independent variable to influence the dependent variable. Mediation indicates that the effect of an independent variable is transmitted through an intervening variable (Musairah, 2015). Related to this study, researchers also have proven in their findings that empowerment can be the mediator variable the relationship of leadership elements. Men and Stacks (2013) founded that empowerment in competence and control mediated the leadership and reputation in the organization. Furthermore, empowerment also mediated the relationship between leadership and innovative work behavior (Badir \& Saeed, 2014).

\section{Theory Development and Hypotheses}

\section{School Performance}

In Malaysia, performance of the school can be accessed from the awarded Cluster School and High-Performance School. Cluster school is a brand that has been given to the school that has been identified as an excellence in their cluster from management aspect and student's development. It is aiming to escalate school excellence in Malaysian educational system and develop school that can be exemplified from other school within the same cluster (MOE,2011). HPS can be defined as a school that have eTos, character, its own identity and uniqueness and prominent in all educational aspects and willing to be competent in world level (MOE, 2011). In efforts to disclose world class educational system and evolving Malaysia as a centre of excellence knowledge, HPS existence is one of the best alternatives that needed to be achieved. Morrison Smith (2009) stated that HPS can be achieved and realized as an instrument in Malaysia educational system.

\section{Leadership and Direction}

Leadership is a leader of the school who are practices effective leadership style, made the determination and implementation of the roadmap in school and practices effective communication.

\section{Organization Management}

Organization management is a leader manage the strategic planning, motivate the school community, have decision-making and instructional skills. School leaders share responsibility, manage human resources and infrastructure properly. They manage school finances and data properly and create a conducive school climate.

\section{Educational Program Management}

Program management is about the school leaders manage curriculum, school sports and take care of students' welfare properly. 


\section{Learning and Teaching}

Learning and teaching based on school leader perceptive in improving students' involvement and monitoring students' work.

\section{Student Achievement}

Achievement of the school organization is based on students' achievement as a practice of students' selection based on ability tests and create positive student practices, succeeded in forming student outcomes and personality.

\section{Entrepreneurial Leadership}

Entrepreneurial leadership are the leadership with characteristics of entrepreneur behaviour which include proactive in optimizing the risk, creative and innovative in finding an opportunity. Furthermore, entrepreneurial leadership are related to the concept in managing the changes in some dynamic organization which are resulting in giving a better outcome for their organization. The quality of entrepreneurial leadership is using all the skills that have been implemented in an entrepreneur which is creativity and knowledge (Arawati \& Za'faran, 2010). Knowledge in entrepreneurship is similar to a corporate in giving attention to the process and management system. According to Khairina (2009), there are certain researchers have defined entrepreneur as a leadership, even if it was different from the economic context and dynamic. Furthermore, entrepreneurial leadership is a process in developing an entrepreneur vision and mission that will inspired the organization to create an objective that need to be achieved (Agbim, Owutuamor \& Oriarewo, 2013). Entrepreneurial leadership also have four main components which are proactive, innovative, creativity and risk taking (Ichrakie, 2013; Agbim, Ayatse \& Oriarewo, 2013; Hejazi, 2012; Barba-Sanchez \& Atienza-Sahuquillo, 2010; Strubler \& Redekop, 2010). It is:

\section{Proactive}

Proactive can be defined as always accept every failure responsibility as one of the assets to achieve goal or mission in a way to make their organization stay in the right path. Furthermore, proactive leader always predicts every incoming problem and thinking all of that are important in order to make changes (McCarthy, Puffer \& Darda, 2010; Muller \& Granese, 2012; Gibbs, 2010; Saldaria, 2012).

\section{Creativity}

Creativity is a thinking process that is motivating in realizing new idea and as a new venture that is more on reality. In context of creativity, it is can be defined as a combination of new and old idea. New idea is needed and old idea need to be studied and assessed. It is a process in looking back, choosing, replacing, intervention of two ideas and skills (Burton, 2012).

\section{Innovative}

Innovative in the entrepreneurial leadership is a tendency and ability to create a creatively, develop a novel and useful a quality idea in opportunity recognition, resources of utilization, innovative development dedicated to achievement, value making and problem solving (Pihie, Asimiran \& Bagheri, 2014).

\section{Risk Taking}

Risk taking in entrepreneurial leadership is a willingness to absorb uncertainty and take the burden of responsibility for the future. Create and develop in diverse phases of the organization, progress and growth. Otherwise developing outside mentors and making a maintainable organization as self-capabilities of entrepreneurial leadership. Develop a group 
of personal and practical capabilities to be able to effectively develop vision and do the challenging responsibilities and roles of entrepreneurial leadership (Ichrakie, 2013).

\section{Strategy}

Strategic in entrepreneurial leadership refers to the ability to determine the organization system in a comprehensive manner taking into account its resources, people and strategy, as well as the organization model that an organization adopts. The strategic also addresses strategic thinking that entrepreneurial leadership must have to ensure the vision of future possibilities that is shared, so that the organization will have a sense of direction, destiny and discovery. Furthermore, the strategic injects flexibility in making decisions and a willingness to face ambiguity. The ability to think in time by understanding the gap between the current reality and future possibilities would improve the quality of decision-making and the speed of implementation. Strategic dimension also focusses to the capacity to develop good hypotheses and to efficiently in the context of a complex and changing organization environment (Musa \& Fontana, 2014).

\section{Communicative}

Communicative of entrepreneurial leadership refers to the how such vision of future possibilities is shared throughout the organization. It deals with the ability to persuade members of the organization, to manage conflicts and to foster knowledge management by understanding emotions in social interactions. Communication is important for effective entrepreneurial leadership, which it first deals with influencing others toward a goal through persuasion for upward, lateral and downward influence. Entrepreneurial leadership shares vision of future possibilities enabling an organization to transform its current transaction sets through adaptation, and leading, through direct involvement, a process of value creation for its stakeholders employing innovation to achieve competitive advantage, and a package of resources to respond to recognized (Musa \& Fontana, 2014).

\section{Motivational}

Motivational of entrepreneurial leadership refers to the human action within the organization that affects both motivation and cognition of people in the organization. Human motivation plays a critical role in the entrepreneurial process. It addresses the ability to motivate people in the organization, to understand the needs of the organization, to maintain an entrepreneurial spirit in people within the organization and to have the self-confidence to influence others. Entrepreneurial leadership is all about managing and instituting transformational and social enactment through positive motivation (Musa \& Fontana, 2014).

\section{Personal}

Personal of entrepreneurial leadership refers to the factors relating to creativity, stability, proper resource allocation and discipline. Creativity in personal deals with the creative skills to organize the needed resources and enact the role of framing the challenge. Stability refers to emotional stability at the individual level, passion and the commitment of the organization to entrepreneurial activities. Proper resource allocations refer to managing resources and maintaining dynamic capabilities to enhance knowledge management within the organization, which in turn could support efforts to recognize opportunities, while organizational discipline deals with building a bridge that links entrepreneurship and strategic management (Musa \& Fontana, 2014). 


\section{Empowerment}

Empowerment is about a set of practices as an authority delegation and responsibility towards employees, self-manage in team work and flexible hierarchy (Krishnan, 2012). Empowerment is also about a process of enhancing feeling of self-efficacy among organization team by the identification of condition, foster powerlessness and their removal by informal techniques and formal organizational practices in providing efficacy information (Tung \& Chang, 2011). Men and Stacks (2013) mentioned that empowerment is the symmetrical concept of power, the collaboration in increasing the power and benefit of organization performance.

\section{Climate}

This empowerment climate dimension focused on addressing the school inscribed as having friendly and welcoming the work environment, open and honest in two-way communication. The leaders share the information so that all can do the jobs well, culture values both positive feedback and constructive criticism. Association in conversing about work issues with leaders and working together across school to solve the students' problems.

\section{Psychological}

Psychological empowerment dimension refers to the leaders permitted to make a decision and feel necessary to do the job effectively. Leaders are encouraged to come up with new and better ways of doing thing and involved in decision that affect teachers work and ideas of leaders about the school are given serious consideration.

\section{The Relationship Entrepreneurial Leadership, Empowerment and School Performance}

Many researchers have proven in their findings that empowerment can be the mediator variable in the leadership relationship. Men and Stacks (2013) founded that empowerment in competence and control mediated the leadership and reputation in the organization. Furthermore, empowerment also mediated the relationship between leadership and innovative work behaviour (Badir \& Saeed, 2014). The finding is also supported by Albrecht and Andreetta (2011) that empowerment also mediated the influence of leadership on the engagement of effective commitment with the health service workers sampling. The psychological empowerment partially mediated the relationship of leadership behaviour and intention to stay (Dewettinck \& Ameijde, 2011). The psychological empowerment can be seen as the respective cause and effect of insinuating that leaders can have an influence on the empowering experiences of the subordinates (Munjuri \& Obonyo, 2015). The empowerment can be mediated for the relationship between transformational leadership and followers' welfare (Krishnan, 2012).

Several studies have shown that empowerment is suitable mediate for the variable of any relationship. There are essentially two types of empowerment given as climate and psychological (Krishnan, 2012). Men (2011) submitted that the structural and psychological approaches are not antithetical rather treating the structuring acts as antecedents leading employees psychological states provides a comprehensive perspective of the empowerment phenomenon.

Risk taking positively associated to the empowerment, whereas leadership is inversely associated with perceived crisis proneness (Sheaffer, Bogler \& Sarfaty, 2011). Cekmecelioglu and Ozbag (2014) founded that empowerment components including psychological and climate are found to be significantly related to creativity. Accordingly, 
when an employee perceives that their requirements are meaningful and personally valuable, they can increase their creative activities by willingly spending time and effort necessary to thoroughly identify a problem, search for extensive information, and generate multiple ideas from different perspectives (Sun, Zhang, Qi and Zhen, 2012; Zhang and Bartol; 2010). According to the Erkutlu and Chafra (2012), proactive is positively associated with empowerment. William, Parker \& Turner (2010) founded that empowerment leads to a proactive orientation towards job, management and organization. Luoh, Tsaur \& Tang (2014) also mentioned that empowerment play a buffering role relationship to the innovative. In addition, empowerment may enhance employees' intrinsic motivation, leading to a higher level of innovation (Chan \& Lam, 2011).

Tung and Chang (2011) indicated that empowerment has a high potency to perform tasks and these tasks are found to be more meaningful and impactful leading to higher intrinsic of the motivation. Tung et al., (2011) also added that empowerment requires communication interaction and cooperation among members and the ultimate team goal cannot be achieved unless all members communicate interactively collaborate on task completion. Furthermore, the empowerment exhibits higher levels of affinity and personal trust in one another with higher levels of satisfaction and effective attraction to the team. Empowerment also have contributed to team performance on issues such as implementation of strategies toward organization goals.

H1: Empowerment mediates the relationship between entrepreneurial leadership and school performance.

Specifically, this hypothesis is:

$\mathrm{H}$ (a) Empowerment mediates the relationship of risk taking and school performance.

$\mathrm{H}$ (b) Empowerment mediates the relationship of creativity and school performance.

$\mathrm{H}$ (c) Empowerment mediates the relationship of proactive and school performance.

$\mathrm{H}$ (d) Empowerment mediates the relationship of innovative and school performance.

$\mathrm{H}$ (e) Empowerment mediates the relationship of personal and school performance.

$\mathrm{H}$ (f) Empowerment mediates the relationship of communicative and school performance.

$\mathrm{H}(\mathrm{g})$ Empowerment mediates the relationship of personal and school performance.

$\mathrm{H}$ (h) Empowerment mediates the relationship of motivational and school performance.

\section{Research Objective}

a) To determine the influence of innovative, proactive, creative, risk taking, strategy, communicative, motivational and personal towards school performance in Malaysia.

b) To identify the influence of innovative, proactive, creative, risk taking, strategy, communicative, motivational and personal to the empowerment (psychological \& climate).

c) To examine the influence of psychological to the school performance.

d) To examine the influence of climate to the school performance.

e) To examine the influence of empowerment (psychological and climate) play role as a mediator on the relationship between innovative, proactive, creative, risk taking, strategy, communicative, motivational and personal toward school performance in Malaysia. 
Table 1.0 Framework

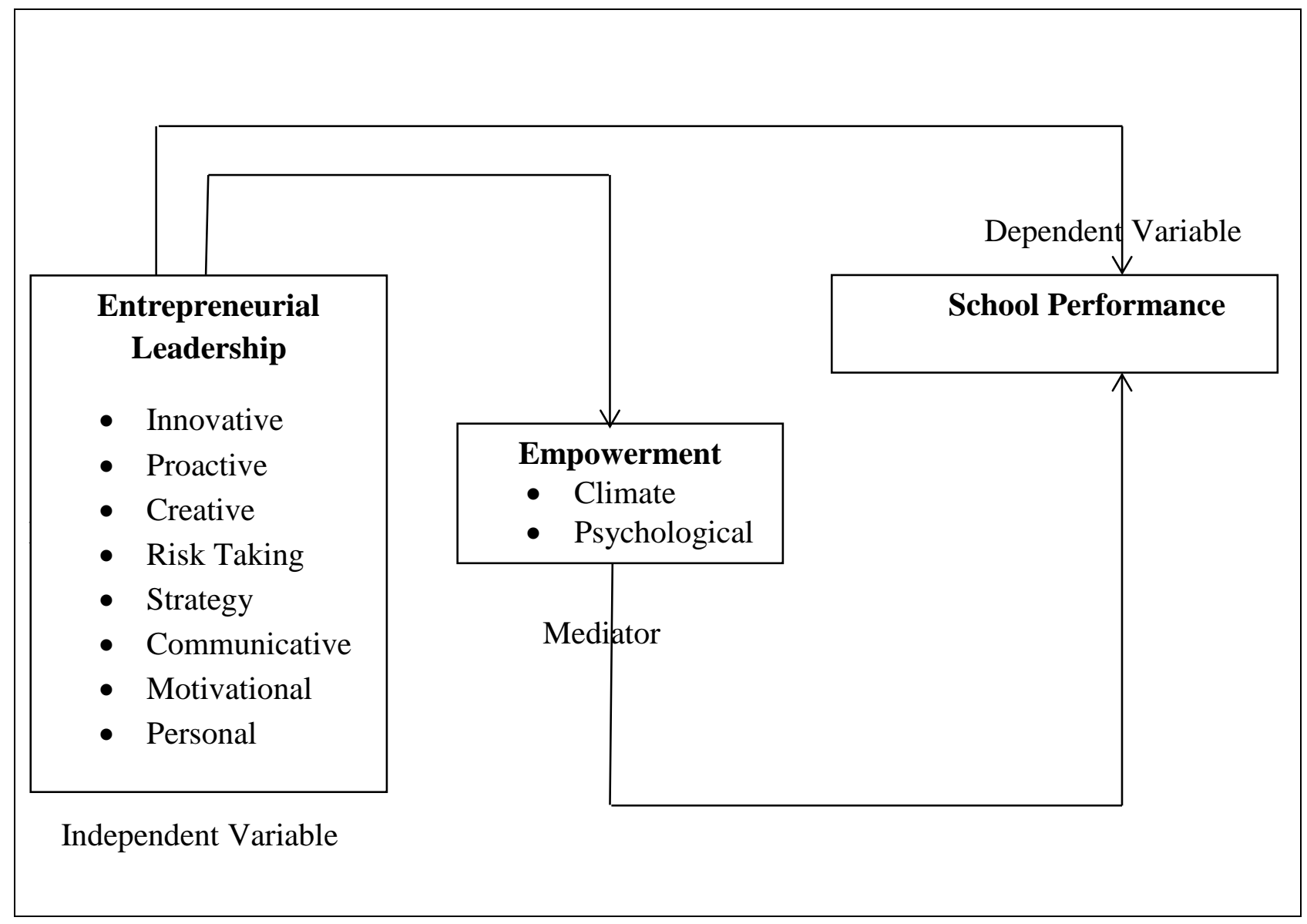

The conceptual framework in this study is second order based on the variable of independence variable and mediator. The Entrepreneurial leadership included eight dimension of innovative, proactive, creative, risk taking, strategy, communicative, motivational and personal. Mediator of empowerment included two dimension of climate and psychological and first order of school performance. This variable and dimension based on past studies of the models and underpinning theory.

\section{Research Method}

\section{Study Population and Sample Size}

The population for this study is the school administrators of the school in Malaysia public school. The school administrators including Senior Assistant of Administration, Senior Assistant of Student Affair and Senior Assistant of Co-Curriculum. The three administrators selected based middle position in evaluate their headmaster or principal in representing school organization. These school organization selected can be categorised the school lowest and highest awarded excellence cluster school and high-performance school. The selection school in this study will be based on non-clusters school and clusters school: 
Table 1.2 Sample Size

\begin{tabular}{|c|c|c|c|}
\hline State & Secondary School & Primary School & Total \\
\hline W.P Putrajaya & 11 & 14 & $25 \times 3=75$ \\
\hline W.P Labuan & 10 & 17 & $27 \times 3=81$ \\
\hline Perlis & 30 & 74 & $104 \times 3=312$ \\
\hline Johor & 20 & 20 & $40 \times 3=120$ \\
\hline \multicolumn{3}{|c|}{ Krejcie and Morgan Table $(588=600)$} & $600 N=234 S$ \\
\hline
\end{tabular}

The lowest performance school selected in WP Putrajaya, WP Labuan and Perlis were including all school except the clusters or high-performance school. The reason is because the three states only awarded titles to two or three schools. The Johor state has the highest received awards and the schools selected are limited to 20 primary schools and 20 secondary schools. The random selection is based on the schools that have received excellence cluster school and high-performance school titles.

\section{Measurement}

\section{School Performance}

School performance is measured with 22 items across the five dimensions namely leadership and direction ( 8 items), organization management (5 items), education programme management (3 items) learning and teaching (3 items) student achievement (3 items). The questionnaires were adapted from Malaysia Education Standard Quality (2010) and supported by Sammons, Hilman \& Mortimore (1995).

\section{Entrepreneurial Leadership}

Entrepreneurial leadership is measured with 53 items across the eight dimensions namely creative (3 items), risk taking ( 3 items), proactive ( 8 items), innovative (4 items), strategic (10 items), communicative (9 items), motivational (7 items) and personal (9 items). The questionnaires of entrepreneurial leadership items were adapted from Thornberry (2006); Fernald, Solomon and Tarabishy (2005); Tierney and Farmer (2004); Gupta, MacMillan and Surie (2004);Becherer, Mendenhall and Eickhoff (2008); Chen (2007); D'Intino, Boyles, Neck, Hall (2008); Mumford (2002); Cogliser and Brigham (2004); McGrath and MacMillan (2000) ; Musa and Fontana (2014); Hejazi, Maleki and Naeiji (2012).

\section{Empowerment}

Empowerment is measured with 10 items across the two dimensions namely climate (6 items) and psychological (4 items). The empowerment dimension measurement was adapted from (Blanchard, Carlosh \& Randolph,1999; Seirbert, Silver \& Randolph, 2004; Spreitzer, 1995). The dimension including climate and psychological. 


\section{Finding and Result}

This research design is suitable and most efficient in light of Malaysian public schools context. Collecting data for the academic purpose from various level of Malaysian public schools viewed extremely difficult. Off total 588 questionnaires distributed, 182 were collected and valid for data analysis is 171 as shown in Table 1.3. Thus, the response rate is 29 percent. Therefore, the response rate in this study are acceptable for the data analyse.

Table 1.3 Response Rate

\begin{tabular}{lcccc}
\hline $\begin{array}{c}\text { Malaysian } \\
\text { Public School }\end{array}$ & $\begin{array}{c}\text { Number } \\
\text { of School }\end{array}$ & $\begin{array}{c}\text { Questionnaires } \\
\text { Distributed }\end{array}$ & $\begin{array}{c}\text { Response } \\
\text { Rate } \\
\text { Received }\end{array}$ & Valid \\
\hline W.P Putrajaya & 25 & 75 & 24 & 21 \\
W.P Labuan & 27 & 81 & 36 & 34 \\
Perlis & 104 & 312 & 73 & 71 \\
Johor & 40 & 120 & 49 & 45 \\
\hline Total & $\mathbf{1 9 6}$ & $\mathbf{5 8 8}$ & $\mathbf{1 8 2}$ & $\mathbf{1 7 1}$ \\
\hline
\end{tabular}

Table 1.3 summarizes the response rates of different school state as a data source for this study. In addition, the respondents were has the alternative way to response and participating in the survey by using URL address for online form. Off the total 171 valid respondent, 103 response were received using online form or web based whereas 68 of response received by booklet or paper based. To evaluate the differences between response techniques, t-test were conducted. Independent sample t-test were conducted on all study variable to examine whether the means for paper based and web based were significantly different from each other.

\section{Common Method Variance}

As this study adopted a self-report, single-informant approach in gathering data, it was necessary to check for the possibility of common method bias (MacKenzie \& Podsakoff, 2012). To address this problem, Harman single factor test was conducted to determine the existence of it. According to MacKenzie \& Podsakoff (2012), common method bias is problematic if a single latent would account for the majority of the explained variance. The unrotated factor analysis performed on all measurement items, extracting 15 factors with eigenvalues greater than 1.0 as shown in the table 1.3. Thus based on result of common method variance was not a serious problem in this study.

Table 1.4: Harman's One Factor Test-Total Variance Explained (CMV)

\begin{tabular}{cccc}
\hline Factor & Total & $\begin{array}{c}\text { Initial Eigenvalues } \\
\text { Variance }(\boldsymbol{\%})\end{array}$ & Cumulative $(\boldsymbol{\%})$ \\
\hline 1 & 13.137 & 77.278 & 77.278 \\
2 & .897 & 5.275 & 82.552 \\
3 & .512 & 3.014 & 85.566 \\
4 & .372 & 2.188 & 87.754 \\
5 & .329 & 1.933 & 89.687 \\
6 & .296 & 1.742 & 91.429 \\
7 & .250 & 1.471 & 92.901 \\
8 & .234 & 1.375 & 94.276 \\
9 & .204 & 1.200 & 95.477 \\
10 & .185 & 1.087 & 95.564
\end{tabular}




$\begin{array}{rrrr}11 & .153 & .902 & 97.467 \\ 12 & .121 & .714 & 98.181 \\ 13 & .107 & .627 & 98.808 \\ 14 & .053 & .310 & 100.000 \\ 15 & .055 & .326 & 100.000\end{array}$

Measurement Model

Based on PLS measurement analysis, Table 1.5 show that the absolute correlation between the construct and its measuring manifest items (factor loading) was above than the minimum threshold criterion 0.4. The factor loading was ranging from 0.546 to 0.899 and satisfied the requirement of the psychometric reliability test. According to table 4.7 shown, there are no items removed because the factor loading was 0.4 above.

Table 1.5: Quality Of The Measurement Model

\begin{tabular}{|c|c|c|c|c|c|}
\hline Construct & Items & $\begin{array}{l}\text { Factor } \\
\text { Loading }\end{array}$ & AVE & $\mathbf{C R}$ & $\begin{array}{c}\text { Cronbach } \\
\text { Alpha }\end{array}$ \\
\hline Innovative & $\begin{array}{l}\text { EL i } 1 \\
\text { EL i } 2 \\
\text { EL i } 3 \\
\text { EL i } 4\end{array}$ & $\begin{array}{l}0.845 \\
0.694 \\
0.627 \\
0.656\end{array}$ & 0.504 & 0.801 & 0.666 \\
\hline Creative & $\begin{array}{l}\text { EL c } 5 \\
\text { EL c } 6 \\
\text { EL c } 7\end{array}$ & $\begin{array}{l}0.846 \\
0.809 \\
0.899\end{array}$ & 0.726 & 0.888 & 0.811 \\
\hline Proactive & $\begin{array}{l}\text { ELp } 8 \\
\text { EL p } 9 \\
\text { EL p } 10 \\
\text { EL p } 11 \\
\text { EL p } 12 \\
\text { EL p } 13 \\
\text { EL p } 14 \\
\text { EL p } 15\end{array}$ & $\begin{array}{c}0.589 \\
0.789 \\
0.630 \\
0.581 \\
0.743 \\
0.628 \\
0.692 \\
0.809\end{array}$ & 0.473 & 0.876 & 0.838 \\
\hline Risk Taking & $\begin{array}{l}\text { ELrt } 16 \\
\text { ELrt } 17 \\
\text { ELrt } 18\end{array}$ & $\begin{array}{l}0.839 \\
0.742 \\
0.802\end{array}$ & 0.633 & 0.837 & 0.709 \\
\hline Strategy & $\begin{array}{l}\text { ELs } 19 \\
\text { EL s } 20 \\
\text { EL s } 21 \\
\text { EL s } 22 \\
\text { EL s } 23 \\
\text { EL s } 24 \\
\text { EL s } 25 \\
\text { EL s } 26 \\
\text { EL s } 27 \\
\text { EL s } 28\end{array}$ & $\begin{array}{c}0.808 \\
0.824 \\
0.768 \\
0.730 \\
0.644 \\
0.808 \\
0.736 \\
0.828 \\
0.708 \\
0.802\end{array}$ & 0.589 & 0.935 & 0.922 \\
\hline Communicate & $\begin{array}{l}\text { ELcm } 29 \\
\text { ELcm } 30 \\
\text { ELcm } 31 \\
\text { ELcm } 32 \\
\text { ELcm } 33\end{array}$ & $\begin{array}{l}0.769 \\
0.712 \\
0.724 \\
0.648 \\
0.699\end{array}$ & 0.534 & 0.911 & 0.890 \\
\hline
\end{tabular}




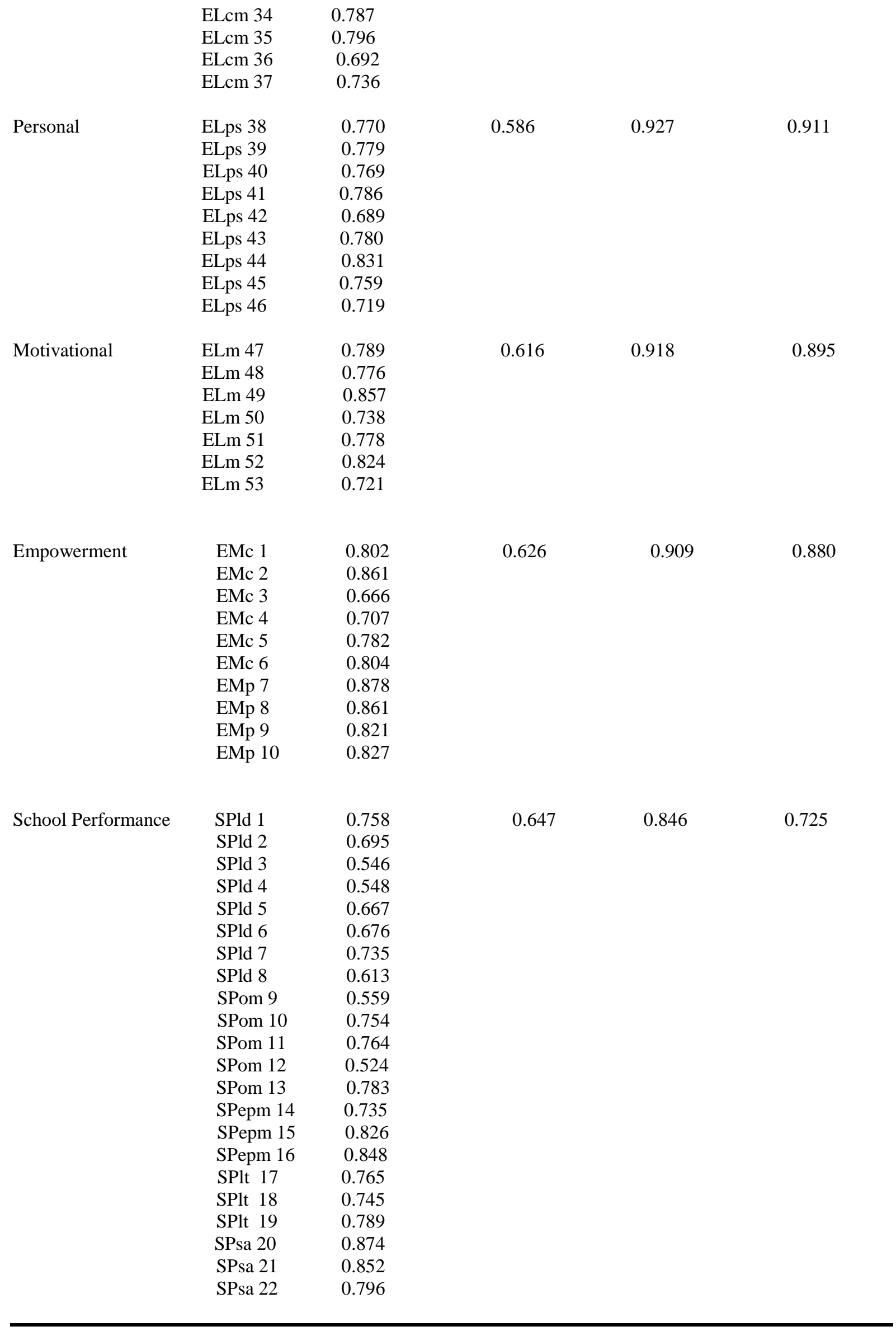


Note: Composite reliability $(\mathrm{CR})=$ (square of the summation of the factor loadings $) /($ (square of the summation of the summation of the factor loading) / (square of the summation of the error variances) \{. Average variance extracted $(\mathrm{AVE})=($ summation of the square of the factor loadings $) /\{$ (summation of the square of the factor loadings)/(summation of the error variances ) $\} *$ Construct items excluded due to low loading AVE

\section{Hypothesis Testing}

Relationship Entrepreneurial Leadership, Empowerment and School Performance

Table 1.6: Result Of Hypothesis Testing Entrepreneurial Leadership, Empowerment And School Performance

\begin{tabular}{|c|c|c|c|c|c|}
\hline Hypothesis & $\begin{array}{l}\text { Path Relationship Between } \\
\text { Variables }\end{array}$ & $\begin{array}{c}\text { Path } \\
\text { Estimation }(\beta)\end{array}$ & $\begin{array}{c}t \\
\text { Value }\end{array}$ & $\begin{array}{c}p \\
\text { Value }\end{array}$ & Results \\
\hline $\mathrm{H}(\mathrm{a})$ & RT -> EMP & $0.045 n s$ & 0.612 & 0.541 & Not Supported \\
\hline $\mathrm{H}(\mathrm{b})$ & CRE -> EMP & $0.434 * * *$ & 3.735 & 0.000 & Supported \\
\hline $\mathrm{H}(\mathrm{c})$ & PRO -> EMP & $0.396 * * *$ & 3.542 & 0.001 & Supported \\
\hline$H(d)$ & INO -> EMP & $0.106 n s$ & 1.618 & 0.106 & Not Supported \\
\hline $\mathrm{H}(\mathrm{e})$ & COM -> EMP & $0.340 * * *$ & 3.454 & 0.000 & Supported \\
\hline$H(f)$ & PER-> EMP & $0.180 n s$ & 1.733 & 0.084 & Supported \\
\hline $\mathrm{H}(\mathrm{g})$ & STR -> EMP & $0.461 * * *$ & 3.216 & 0.001 & Supported \\
\hline \multirow[t]{2}{*}{$\mathrm{H}(\mathrm{h})$} & MOT -> EMP & $0.009 n s$ & 0.927 & 0.927 & Not Supported \\
\hline & EMP $->$ SP & $0.850 * * *$ & 13.070 & 0.000 & Supported \\
\hline
\end{tabular}

Note: Significant level $=* * * p<0.01 ; * * \mathrm{p}<0.05 ; * \mathrm{p}<0.10 ;$ not significant.

$\mathrm{EL}=$ Entrepreneurial Leadership; $\mathrm{SP}=$ School Performance; EMP = Empowerment; INO = Innovative; $\mathrm{PRO}=$ Proactive;

$\mathrm{CRE}=$ Creative $; \mathrm{COM}=$ Communicative, $\mathrm{PER}=$ Personal $; \mathrm{STR}=$ Strategic $; \mathrm{MOT}=$ Motivational.

Table 1.6 below explains the analysis result of relationship between entrepreneurial leadership to empowerment is significant. In addition, the result also revealed that entrepreneurial leadership variable provide an evidence that significant support to empowerment. However, the variable of innovative, risk taking and motivational provide evidence not significance toward empowerment. The result for empowerment to school performance shows that there is a significant and positive relationship $(\beta=0.850, \mathrm{t}=13.070$, $\mathrm{p}<0.01)$.

Assessment of Coefficient of Determination $\left(R^{2}\right)$ and Prediction Relevance $\left(Q^{2}\right)$

The result shown in Table 1.6 revealed that empowerment and school performance by the Malaysian public-school falls under moderate level that explained entrepreneurial leadership. The result shown $89.3 \%$ for empowerment and $71.3 \%$ of school performance. In addition, the indices for the value of $\mathrm{Q}^{2}$ after blindfolding analysis are shown in Table 1.7 summarized that the value of $\mathrm{Q}^{2}$ above the zero. Thus, providing support that the model predictive relevance regarding the endogenous latent variable.

Table 1.7 Result of $\mathrm{R}^{2}$ and $\mathrm{Q}^{2}$ values

\begin{tabular}{lcc}
\hline Latent Variable & $\mathbf{R}^{2}$ Value & $\mathbf{Q}^{2}$ Value \\
\hline Empowerment & 0.893 & 0.497 \\
School Performance & 0.713 & 0.331 \\
\hline
\end{tabular}




\section{Assessment of Effects Size $\left(f^{2}\right)$}

The last analysis for structural model evaluation is the $\mathrm{f}^{2}$, effect size. The $\mathrm{f}^{2}$ is the complementary test of $\mathrm{R}^{2}$, whereby changes to $\mathrm{R}^{2}$ was observed with the omission of any selected exogenous variable from the model (Hair et al., 2014). The $\mathrm{f}^{2}$ analysis used to evaluate the independent variable's incremental explanation of a dependent variable (Ringle et al., 2012). The change was calculated by re-estimating the model twice (with and without the exogenous latent variable inclusion). The $\mathrm{f}^{2}$ result for the model is shown in Table 4.16. Based on the formula expression for effect size $f^{2}=\left(R^{2}\right.$ included $-R^{2}$ excluded $) /\left(1-R^{2}\right.$ included $)$, the result revealed that according to the rule of thumb, the effect size were small $\left(f^{2}>0.02\right)$.

Table 1.7: Effect Size Calculation For The Model

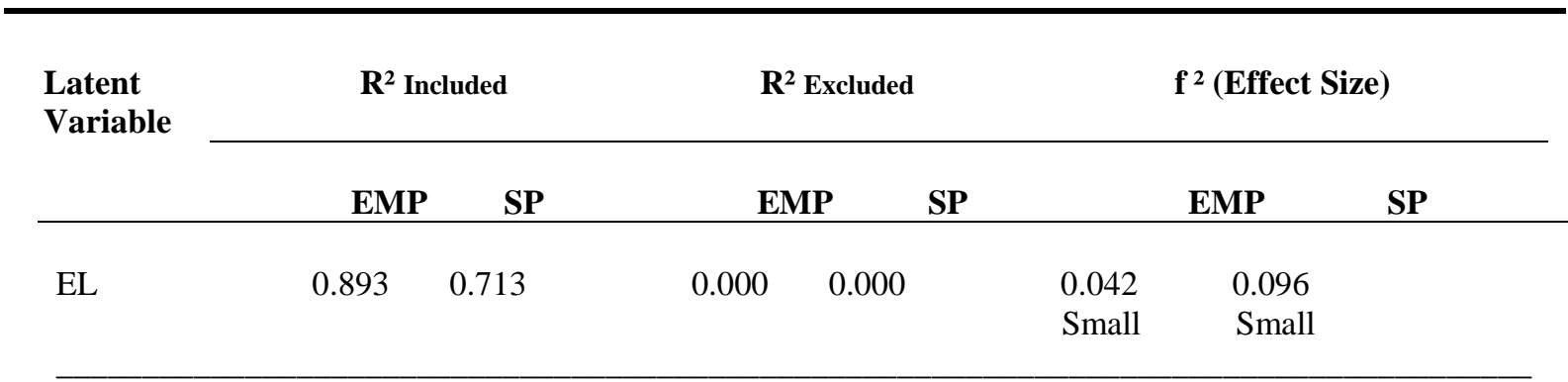

Note: $\mathrm{f}^{2}<0.019=$ None; $0.02<\mathrm{f}<0.149=$ Small; $0.15<\mathrm{f}<0.349=$ Medium; $\mathrm{f}>0.35=$ Large

$\mathrm{EL}=$ Entrepreneurial Leadership; EMP $=$ Empowerment: $\mathrm{SP}=$ School Performance

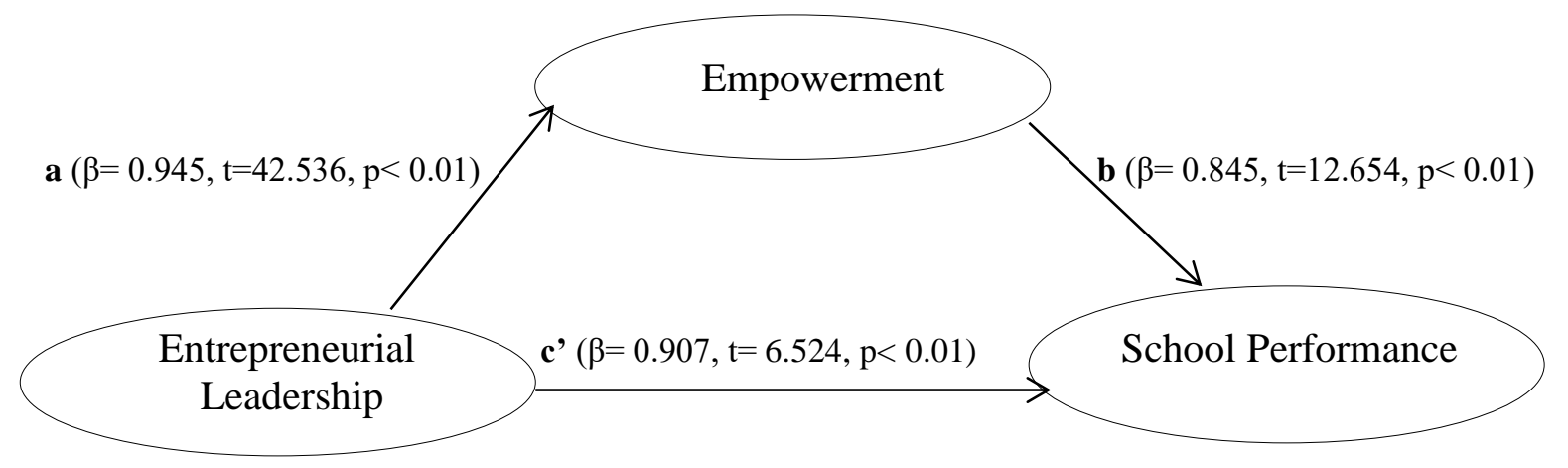

Figure 1.0 Mediating Model Of Empowerment Between Entrepreneurial Leadership And School Performance

\section{Conclusion}

\section{Discussion}

The empirical study has proven that empowerment can be the mediator variable in leadership relationship. This study supports the study by Men and Stacks (2013) that empowerment in competence and control mediated the leadership and reputation in the organization. Furthermore, empowerment also mediated the relationship between leadership and innovative work behaviour (Badir \& Saeed, 2014). The finding in this study also supported by Albrecht and Andreetta (2011) that empowerment also mediated the influence of leadership on the engagement of effective commitment with the health service workers sampling. The psychological empowerment partially mediated the relationship of leadership behaviour and intention to stay (Dewettinck \& Ameijde, 2011). The psychological empowerment can be seen as the respective cause and effect of insinuating that leaders can have an influence on the empowering experiences of the subordinates (Munjuri \& Obonyo, 2015). The empowerment 
can be mediated for the relationship between transformational leadership and followers' welfare (Krishnan, 2012).

Empirical study have shown that empowerment is suitable mediate for the variable of leadership relationship. There are essentially two types of empowerment given as climate and psychological (Krishnan, 2012). Men (2011) submitted that the structural and psychological approaches are not antithetical rather treating the structuring acts as antecedents leading employees psychological states provides a comprehensive perspective of the empowerment phenomenon. Risk taking positively associated to the empowerment, whereas leadership is inversely associated with perceived crisis proneness (Sheaffer, Bogler \& Sarfaty, 2011). Cekmecelioglu and Ozbag (2014) founded that empowerment components including psychological and climate are found to be significantly related to creativity and performance. Accordingly, when an employee perceives that their requirements are meaningful and personally valuable, they can increase their creative activities by willingly spending time and effort necessary to thoroughly identify a problem, search for extensive information, and generate multiple ideas from different perspectives (Sun, Zhang, Qi and Zhen, 2012; Zhang and Bartol; 2010). According to the Erkutlu and Chafra (2012), proactive is positively associated with empowerment. William, Parker \& Turner (2010) founded that empowerment leads to a proactive orientation towards job, management and organization. Luoh, Tsaur \& Tang (2014) also mentioned that empowerment play a buffering role relationship to the innovative. In addition, empowerment may enhance employees intrinsic motivation, leading to a higher level of innovation (Chan \& Lam, 2011).

Tung and Chang (2011) indicated that empowerment has a high potency to perform tasks and these tasks are found to be more meaningful and impactful leading to higher intrinsic of the motivation. Tung et al., (2011) also added that empowerment requires communication interaction and cooperation among members and the ultimate team goal cannot be achieved unless all members communicate interactively collaborate on task completion. Furthermore, the empowerment exhibit higher levels of affinity and personal trust in one another with higher levels of satisfaction and effective attraction to the team. Empowerment also have contributed to team performance on issues such as implementation of strategies toward organization goals. As the conclusion this finding show variable of entrepreneurial leadership and eight of dimension are significant to the empowerment towards to the school performance. In addition, the empowerment is suitable as a mediator between of entrepreneurial leadership and school performance in Malaysia. Therefore, to be a good school leader, they have to empower their leader strength of psychological and climate to perform the school organization.

\section{Future Research}

In the future, there are several directions for the researchers to follow. First, entrepreneurial leadership for the future research need to adapt about the eight dimensions of this leadership towards profit or non-profit organization. The next study also makes a research about entrepreneurial leadership towards school funds in public or private school in Malaysia. The entrepreneurial leadership research is limited study in public or private school.

Second, the future research can attempt to use additional theories such as LMX in order in enhance the proposed a new leadership align by leadership 4.0 toward performances or achievement in organization. The LMX theory occupies a unique position among leadership theories because of its focus on the dyadic relationship between leader and follower. LMX theory was originally referred to as Vertical Dyad Linkage (VDL) theory (Dansereau, Graen 
\& Haga, 1975). According to VDL approach, leaders and followers develop dyadic relationships and leaders treat individual followers differently, resulting in two groups of follower as an in group and out group. The group consists of a small number of trusted followers with whom the leader usually establishes a special higher quality exchange relationship. The out group includes the remaining followers with whom the relationship of the leader remains more formal. Third, the framework can be tested in private school in Malaysia on the basis orientation rather customer satisfaction orientation. In the private school context of profit orientation, the framework could be enhanced by including the competitive pressure variable and including the competitive advantage and sustainability to the research framework.

\section{References}

Agbim, K.C., Oriarewo, G.O. and Owutuamor, Z.B. (2013), "An Exploratory Study of The Entrepreneurial Leadership Capabilities of Entrepreneurs in Anambia State, Nigeria", Journal of Business Management \& Social Sciences Research, Vol. 2 No. 9, pp 68-75. ISSN No: 2319-5614

Barba-Sanchez, V. and Atienza-Sahuquillo, C. (2010). Integration of the environment in managerial strategy: Application of the resourcebased theory of competitive advantage, dynamic capabilities and corporate social responsibilities. African Journal of Business Management, 4(6), 115-1165.

Cekmeclioglu, H.G. and Ozbag, G.K. (2014), "Linking Psychological Empowerment, Individual Creativity and Firm Innovativeness: A Research Manufacturing Industry, Business Management Dynamics, Vol 10, No 3, pp 01-13.

Dewettinck, K. and Ameijde, M.V. (2011), "Linking Leadership Empowerment Behaviour to Employee Attitudes and Behavioural Intentions," Journal of Personnel Review, Vol.40 No 3, pp 284-305. doi: 10.1108/00483481111118621

Erkutlu,H. and Chafra, J. (2012), "The Impact of Team Empowerment on Proactivity: The Moderating Roles of Leader's Emotional Intelligence and Proactive Personality", Journal of Health Organization and Management, Vol. 26 No.5, pp 560 - 577. Doi: $10.1108 / 14777261211256918$

Eyal, O. and Inbar, D.E. (2013), "Developing a Public-School Entrepreneurship Inventory: Theoretical Conceptualization and Emprical Examination", International Journal of Behaviour and Research, Vol.9 No.6, pp 221-244. Doi: 10.1108/13552550310501356

Fontana, A., and Musa, S. (2017) "The Impact of Entrepreneurial Leadership on Innovation Management and its Measurement Validation", International Journal Innovation Science, Vol.9 No 1, pp 2-19. Doi: 10.1108/IJIS-05-2016-0004

Hejazi, S. A. M., Malei, M. M. and Naeiji, M. J. (2012), "Designing a Scale for Measuring Entrepreneurial Leadership in SMEs", International Conference on Economics, Marketing and Management, IPEDR, Vol.28 No.2, pp 71-77.

Hocevar, M.A., Janzen, M.I. and Wilson, C.L. (2012), "Leadership from ground up: Effective schooling in traditionally low performing school".

IAB. (2014). NPQEL Menjana Kepemimpinan Masa Hadapan: Menggilap Permata [NPQEL Generating Future Leaders: Enhancing Gems]. Genting Highlands: Author.

Ichrakie, F. (2013), "Intangible resources as Key Determinants of Job Network Providers' Success: A Resource-Based Study, Australian Journal of Business and Management Research, Vol. 2 No 1, pp 43-63.

Jones, M., \& Harris, A. (2014). Principals Leading Successful Organisational Change: Building Social Capital Through Disciplined Professional Collaboration. Journal of Organizational Change Management, 27(3), 473-485. Doi:10.1108/JOCM-07-20130116 
Kempster, S.J. \& Cope, J. (2010), "Learning to Lead in The Entrepreneurial Context," Journal of Entrepreneurial Behaviour and Research", Vol 16 No 1, pp 5-34. Doi: $10.1108 / 13552551011020054$

Krishnan, V.R. (2012), "Transformational Leadership and Personal Outcomes: Empowerment as Mediator," Journal of Leadership \& Organization Development, Vol. 33 No.6, pp 550-563. doi : 10.1108/01437731211253019

Lu, K., Zhu, J. and Bao, H. (2015), "High Performance Human Resource Management and Firm Performance", Industrial Management \& Data Systems, Vol. 115 No. 2, pp 353-382. Doi :10.11/JMDS-10-2014-0317

Leithwood, K., \& Sun, J. P. (2012). "The Nature and Effects of Transformational School Leadership: A Meta-Analytic Review of Unpublished Research. Educational Administration Quarterly, 48(3), 387-423. Doi:10.1177/0013161x11436268

Malaklolunthu, S., \& Shamsudin, F. (2011), "Challenges in School-Based Management: Case Of a'Cluster School' in Malaysia", Procedia-Social and Behavioral Sciences, 15, 1488-1492. Doi: 10.1016/j.sbspro.2011.03.316

Men, L.R. and Stacks, D.W. (2013), "The Impact of Leadership Style and Employee Empowerment on Perceived Organizational Reputation," Journal of Communication Management, Vol. 17 No 2, pp171-192. doi : 10.1108/13632541311318765

Munjuri, M.C. and Obonyo, P.K. (2015), "Human Capital, Employee Empowerment and Performance of Commercial Banks and Insurance Firm in Kenya", International Journal of Arts and Commerce, Vol.4, No. 6, pp 163-181.

Musairah, S.K. (2015), "Mediaton and Moderation Analysis from the Perceptive of Behavioral Science", Jurnal Intelek, Vol 10 No 1, pp 1-11. ISSN 2231-7716

Park, J.H. (2012), "The Effects of Principal's Leadership Style on Support for Innovation: Evidence From Korean Vocational High School Change", Journal of Asia Pacific Education, Vol 16 No.1, pp 5-34. doi: 10.1007/s12564-011-9182-9

Pihie, Z.A.L., Asimiran, S. and Bagheri, A. (2014), "Entrepreneurial Leadership, Practices and School Innovativeness",South African Journal of Education, Vol.34 No.1. http://www.sajournalofeducation.co.za

Rahimah, H. A., \& Ghavifekr, S. (2014). School Leadership for the 21st century: A Conceptual Overview. Malaysian Online Journal of Educational Management, 2(1), 48-61.

Renko, M.,Tarabishy, A.E, Carsrud, A.L. and Brannback, M. (2015), “ Understanding and Measuring Entrepreneurial Leadership Style", Journal of Human Resources Management, Vol.53 No.1, pp 54-74. Doi: 10.1111/jsbm.12086

Thornberry, N. (2006). Lead Like an Entrepreneur: Keeping the Entrepreneurial Spirit Alive within the Corporation. Fairfield, PA:McGraw Hill.

Tie, F. H. (2012). Leadership for learning in Malaysian schools. In T. T. A. J. MacBeath (Ed.), International handbook of leadership for learning (pp. 419-429). Dordrecht Heidelberg: Springer.

Tierney, P., and S. M. Farmer (2004). "The Pygmalion Process and Employee Creativity", Journal of Management 30(3), 413-432.

Tung, H-L. and Chang, Y-H. (2011), "Effects of Empowering Leadership on Performance in Management Team", Journal of Chinese Human Resource, Vol.2 No. 1, pp 43-60. Doi :10.1108/20408001111148720

Sammon, P., Hillman, J. and Mortimore, P. (1995), "Key Characteristics Of Effective School: A Review of School Effectiveness Research", A Report by the Institute of Education for the Office for Standard in Education. London: University of London. (ERIC Document Reproduction No ED 231 182) 
Sheaffer, Z., Bogler, S. and Sarfaty, (2011), "Leadership Attributes, Masculinity and Risk Taking as Predictors of Crisis Proneness, Gender in Management", An International Journal, Vol 26, No 2, pp 163-187. doi : 10.1108/1754241111116563

Sun, L-Y., Zhang, Z., Qi, J. and Zhen, Z.X. (2012), "Empowerment and Creativity: A Cross Investigation", The Leadership Quarterly, Vol.23 No.1, pp 55-65. 